\title{
Age structure, annual growth, and variance of size-at-age of the shrimp Heterocarpus reedi
}

\author{
Rubén Roa ${ }^{1,2, *}$, Billy Ernst ${ }^{2}$ \\ ${ }^{1}$ Instituto de Fomento Pesquero, Sede Zonal V-IX Regiones, Casilla 347, Talcahuano, Chile \\ ${ }^{2}$ Departamento de Oceanografía, Universidad de Concepción, Casilla 2407, Concepción, Chile
}

\begin{abstract}
Age-structure analysis provides information on important aspects of the population biology of exploited marine species. The pandalid shrimp Heterocarpus reedi inhabits the benthic environment of the continental shelf off central Chile, and is one the main and oldest Chilean crustacean fisheries. We analysed 10 years of length-frequency data (LFD) from sampling of the commercial catch, covering a period of $27 \mathrm{yr}$, to examine the age structure, annual average growth, and variance of sizeat-age. In the absence of actual age evidence, we classified year classes into age classes using a conceptual model based on 2 assumptions: first, individuals grow as they age, and second, the population has an annual cycle of recruitment. The procedure can be applied to a collection of LFD from severa] years. Two components of variance of size-at-age are calculated: the within-year-class variance, due to pre-settlement processes, and the among-year-classes variance, due to post-settlement processes. An across-ages coefficient of variation of size-at-age for each variance term is provided as a single quantity useful for interspecific comparisons. The age structure of the exploited fraction of $H$. reedi is made up of 5 age classes, with age class IV as the most represented. Annual average growth follows a von Bertalanffy growth function with significantly different parameterization for both sexes. Females are smaller and highter than males at early ages but larger and heavier than males at late ages. The within-year-class variance proved to be a conservative quantity that does not change with age. Total variance of size-at-age for all ages and both sexes is mostly due to pre-settlement processes.
\end{abstract}

KEY WORDS: Population biology Age structure $\cdot$ Growth $\cdot$ Size variance $\cdot$ Shrimp

\section{INTRODUCTION}

The analysis of age structure through time in seasonally reproducing animals provides information on several aspects of population dynamics. For fisheries scientists it is the basis for a family of methods of assessment of exploited populations (Megrey 1989), and for population biologists it is a tool in studying age- and timedependent processes, such as growth, mortality, and recruitment variability.

Age-structure analysis is not confined to animals that can be aged directly through age marks in body structures, such as vertebrates and invertebrates with permanent hard structures. Crustaceans can be aged by keeping organisms in captivity (Plaut \& Fishelson

\footnotetext{
·E-mail: rroa@buho.dpi.udec.cl
}

1991, Hill 1992), by mark-recapture experiments (Campbell 1983, Taylor \& Hoenig 1990, Fitz \& Weigert 1991, Somers \& Kirkwood 1991), by physiological correlates of age (Sheehy et al. 1995), and by using mixture distribution analysis of length-frequency data (LFD) (methodological papers: Macdonald \& Pitcher 1979, Fournier et al. 1990; applications: Anderson 1991, Fournier et al. 1991, France et al. 1991, Bergström 1992, Roa 1993, Roa \& Bahamonde 1993). When a time series or a yearly collection of LFD is available, mixture distribution analysis can be used to identify several year classes from different years, and then to estimate temporal averages of properties related to the age structure. For example, it is possible to estimate a temporal average of the growth function This is a better procedure than following a single cohort through time or analysing a single set of LFD (Fournier \& Breen 1983). Moreover, by having several year 
classes (from different years) in each age class, it is possible to evaluate the temporal variance of cohort properties, such as mean size-at-age (Roa 1993). In exploited populations, the proportion of participation in the distribution mixtures at age, which in fishery science is called year-class relative strength, is indicative of the temporal average age at which an exploited population is completely recruited to a fishing fleet or gear

Age structure obtained from analysis of LFD (or direct age-frequency data from hard body structures) from several years can also be used to study the effect of recruitment variability on cohort properties and population structure. Marine benthic ecologists are now aware that the magnitude of recruitment, and its variability, is a major determinant of population processes in post-settlement life (Underwood \& Denley 1984, Connell 1985, Peterson \& Summerson 1992. Doherty \& Fowler 1994). However, even under cunditions of constancy in the number of settlers entering a population on every recruitment season, there is still recruitment variability associated with the duration of the periods of broadcasting, pelagic larval life, and settiement that induces variability in cohort properties in the post-settlement period. For example, Roa (1993) showed that variance of size-at-age for all ages in the squat lobster Pleuroncodes monodon was mainly due to the inherent variability of year classes, acquired during pre-settlement life, and not to environmental influences encountered during post-settlement life. For this task, the author identified 2 sources of variance of size-at-age: the within-year-class and the among-year-classes variance. The within-year-class variance is that resulting from the size distribution of individuals born during the same reproductive season, averaged over several years, while the amongyear-classes variance is that resulting from the mean size of individuals of the same age born in different reproductive seasons.

The pandalid shrimp Heterocarpus reedi Bahamonde, 1955 inhabits the bottom on the continental shelf and upper slope off central Chile, is commercially exploited by a trawling fleet, and is one of the main and oldest Chilean crustacean fisheries. In this paper we use a collection of LFD from 10 years to analyse the age structure of $H$. reedi, modifying the procedure introduced by Roa (1993). In this way we (1) identify the average age at which the shrimp is completely recruited to the fishing fleet, (2) estimate the parameters of an annual average growth equation, and (3) obtain estimates of within year class and among year classes variances of size-at-age. This latter task allows us to conclude that pre-settlement processes are more important than post-settlement processes in determining total variance of size-at-age.

\section{MATERIALS AND METHODS}

Data source. We analysed length frequency data (LFD) from 10 years of sampling of the catch of the shrimp Heterocarpus reedi, on ports of the Fifth Administrative Region of central Chile. Each data set corresponds to the cumulative sampling during any one year. Body size was measured as carapace length (CL) to the nearest millimeter, measuring from the base of the eye socket dorsally, along a line parallel to the mid-line, to the posterior edge of the carapace. The fishing was exclusively performed by a trawling fleet operating on soft bottoms of the Chilean continental shelf and upper slope from about $31^{\circ} 30^{\prime}$ to $33^{\circ} 30^{\prime} \mathrm{S}$. Appropriate sample size (>2500 individuals) was available for almost every year of the collection (see Fig. 1). The collection includes 3 periods: from 1968 to 1973 , 1981, and from 1992 to 1994, and, as far as we know, standard procedures were applied for sample collection and size measurement along the 27 yr covered by our data. To support this assumption, we performed a 2-sample Kolmogorov-Smirnov test (Steel \& Torrie 1985) comparing the size structure of the period 1968-1973 with the period 1992-1994. A homogeneous size structure for the 2 periods would allow the use of the pooled sample for annual growth and variance of size-at-age analyses. A further sample from 1995 was exclusively used to compare mass at length between sexes.

Age structure. LFD analysis was performed separately for males and females, since we expected to find sex-specific age structure and growth parameters. To reveal age structure from LFD of every year-sex combination we used the statistical-numerical algorithm MIX of Macdonald \& Pitcher (1979), with quasi-Newton as the convergence algorithm. In general terms, MIX analysis considers a histogram as the sampling representation of a mixture of probability density functions (PDF), and was designed to analyse one histogram, or mixture of PDFs, at a time. In our population application, we selected normal PDFs each corresponding to a year class. For every LFD set, the number of parameters to be estimated was the assumed number of age classes prosent in the mixture $(r)$ times the 3 parameters of each year class (proportion of participation in the distribution mixture, and mean and standard deviation of size-at-age). The assumed number $r$ was obtained using the same criteria as in Roa (1993). The analysis was done without constraints, except for years 1969 and 1970 of males, in which the mean size-at-age was constrained to lie on a growth curve. Unconstrained analysis for these data did not yield parameter convergence. As a result, 3 male year classes out of 31 (see 'Results') yielded mean sizes without a standard error. 
The year classes for each sex identified from the whole collection of LFD sets have to be classified into age classes. This is equivalent to saying that the year classes have 2 indices, 1 for calendar year and 1 for age class, and that it is necessary to allocate the ageclass index to the different year classes. This is the critical aspect of our multiple-sample analysis of age structure. For this task, we introduced 2 fundamental assumptions. First, individuals from older age classes tend to have greater mean size, because there is a growth function governing the movement from younger to older age classes. Second, for every calendar year, there will be only 1 and no less than 1 recruitment period leading to 1 year class. That is, each year the population would supply itself with a new batch of recruits. Support for the first assumption comes from growth studies in several decapod crustaceans (see references in Roa 1993), while support for the second assumption in the case of the shrimp Heterocarpus reedi comes from parallel research done on reproductive biology of the species (Campodónico, Farías, Alegria \& Roa unpubl.). Under the first assumption, the whole set of year classes has to be sorted into an ordered sequence of ascending mean size to disclose age structure. Under the second assumption, every age class of a correct classification will contain only 1 year class from every calendar year Furthermore, if a year class from year $y$ is present in age classes $a-1$ and $a+1$, then another year class from year $y$ must be present in age class $a$; otherwise, there would be a missing year class, which violates the second assumption.

These 2 assumptions lead to the following procedure for classifying a set of year classes from different years into age classes: (1) the whole set of year classes must be sorted into a sequence of ascending mean size, (2) tentative borders between age classes are outlined by the repetition of year indices within the sequence, and (3) if this initial classification yields missing year classes, then year classes are moved to fill in the gaps in such a way as to minimize the alteration of the sequence. This procedure is a compromise between the first and second assumptions. Step (2) may be performed in either of 2 ways, forward or backward. In the forward fashion, the tentative borders between age classes (marked by a repetition of the year index) are outlined reading from smallest to largest year class mean size. In the backward fashion, reading goes from largest to smallest year class mean size. Forward and backward reading need not yield the same classification of year classes into age classes. The application of the forward or backward reading depends on which alterñative yieluis inte leasi aiteration of the initial sequence in Step (3). Finally, if forward and backward readings yield the same number of alterations, then the fit of the growth equation must be performed with both kinds of reading, and the feasibility of the parameter estimates and the general statistical quality of the fitting will tell which classification must be accepted as valid. Our application of this method for the LFD of male Heterocarpus reedi will illustrate the case in which the initial sequence is not altered at all so that step (3) is not necessary, while the LFD of female $H$. reedi will illustrate the more complicated case in which the fit of the growth equation must be performed for both forward and backward age classifications (see 'Results').

Annual growth. The MIX algorithm is capable of estimating the 3 growth parameters of a simple asymptotic model (the von Bertalanffy equation), when constraining the mean size of the fourth and older year classes to lie on the model. However, this procedure requires a minimum of 4 year classes, a condition that was not met for many years of our data. A different alternative when several year classes from different years are available - i.e. when there are several years of data - is to classify the year classes into age classes, and then to use the increased number of observations of size-at-age with nonlinear statistical software, estimating the parameters of whatever growth equation seems appropriate. We have already explained our procedure of classifying year classes from several years into age classes. Hence, the total number of year classes was used for fitting the growth equation. The plot of mean size-at-age against age clearly implicated a simple asymptotic growth function, the von Bertalanffy equation. Therefore we fitted this model using nonlinear least-squares in the module NONLIN of SYSTAT (Wilkinson 1988), with a quasi-Newton minimization algorithm. A statistical comparison of the growth equation fitted for both sexes was performed using Analysis of Residual Sum of Squares modified for nonlinear least-squares (ARSS; Chen et al. 1992). From the 1995 data, a potential model [mass $=d$ (carapace length $)^{b}$, with $d$ and $b$ as constants] linearized by taking logarithms on both mass and length was fitted using linear leastsquares (module MGLH in SYSTAT; Wilkinson 1988). The comparison between the linear equations of both sexes was done using a combined model with an independent indicator variable (Neter et al. 1985, p. 344) Under such an approach, significant slopes for the indicator variable (0: male; 1 : female) and/or for the interaction between the indicator variable and the continuous one [ln(length)] mean that the 2 regressions are statistically different in intercept and/or slope.

Variance of size-at-age. The collection of year classes classified into age classes allows the computation of within-year-class and among-year-classes vari- 
ance of size-at-age. The within-year-class variance is the weighted mean of all the variances (estimated by $\mathrm{MIX}$ ) of the year classes of a given age class. This mean variance is an inherent property of the year classes, due to the temporal variability of pre-settlement processes, such as larval broadcasting, pelagic larval life, and settlement itself. In other words, it arises as a consequence of a certain level of asynchrony in larval hatching amongst reproductive individuals in the population, and another level of asynchrony in settlement amongst the recruits. The among-year-classes variance is the variance of means around the weighted mean of all year classes of a given age class. This variance of mean sizes results from the different years in which year classes are borm, and is expressed as year classes advance through age classes, in post-settlement life. For those reasons, the former variance was called 'individual' and the latter 'temporal' in Rud (1993). The relative sizes of both kind of variances for a given age class is a measure of how important pre-settlement processes are as compared to post-settlement processes, in generating variance of size-at-age.

We used the following expressions for within-yearclass $\left(\sigma^{2}\right)$ and among-year-classes $\left(\sigma^{2} \gamma\right)$ variance:

$$
\begin{gathered}
\hat{\sigma}_{Y, a}^{2}=\frac{\sum_{i=1}^{r_{a}} \hat{\sigma}_{i, a}^{2} N_{i} \hat{\alpha}_{i, a}}{\sum_{i=1}^{r_{d}} N_{i} \hat{\alpha}_{i, a}} \\
\hat{\sigma}_{Y, d}^{2}=\frac{1}{r_{a}} \sum_{i=1}^{r_{a}}\left(\hat{\mu}_{j, a}-\frac{\sum_{i=1}^{r_{d}} \hat{\mu}_{i, a} N_{i} \hat{\alpha}_{i, d}}{\sum_{j=1}^{r_{d}} N_{i} \hat{\alpha}_{i, a}}\right)
\end{gathered}
$$

where $i$ indexes calendar years; $a$ indexes age classes; $\sigma^{2}$, is a variance estimated by MIX; $N_{i}$ is the sample size for year $i$ (Fig 1); $\alpha_{i, \bar{a}}$ is a proportion of participation in the mixture estimated by MIX; and $\mu_{l, d}$ is the mean of age class a in year $i$ estimated by MIX. The product $N_{i} \alpha_{i, d}$ is weighting year classes according to the number of individuals that belonged to them.

According to our formulation, the distribution of sizeat-age for a period of annual population cycles of recruitment follows a normal density function $(f)$ of the form:

$$
f_{d}(C L)=\frac{1}{\sqrt{2 \pi\left(\sigma_{Y, d}^{2}+\sigma_{Y, d}^{2}\right)}} e^{-\frac{1}{2\left(\sigma^{2} y+\sigma^{2} y_{\gamma, 1}\right.}(C L-\mu)^{2}}
$$

Finally, for the purpose of interspecific comparisons in the magnitude of variance of size-at-age terms, we defined the across-ages within-year-class coefficient of variation $(\mathrm{CV}$, ) as follows

$$
\mathrm{CV}_{Y}=\frac{\sum_{a=1}^{A} N_{a} \hat{\sigma}_{Y, a}}{\sum_{a=1}^{A} N_{a} \hat{\mu}_{d}}
$$

where $N_{a}=N_{1} \alpha_{1, d}$. A similar expression was used to calculate the across-ages among-year-classes coefficient of variation. Note that this quantity is independent of species body size and the number of ages that make up a given population. This standardized quantity was calculated for our data on the shrimp Heterocarpus reedi and compared to results for the squat lobster Pleuroncodes monodon, after having performed a further analysis based on our previously published study on the squat lobster (Roa 1993).

\section{RESULTS}

\section{Age structure}

For every year-sex combination, large sample size allowed for visual estimation of the number of year classes present in each LFD set (Fig. 1). The total number of year classes identified from the 10 years of data was 31 in males and 39 in females, with 3 year classes per year of data as the most common result for both sexes (Fig. 1). For each year class, the 3 parameters were estimated (mean size and standard deviation of the normal PDF, and proportion of participation in the distribution mixture) with fairly low standard errors (Table 1).

A comparison of the size structure from the period 1968-1973 with the period 1992-1994 indicated temporal homogeneity for males (Kolmogorov-Smirnov $D$ statistic $\left.=0.211, N_{1}=19, N_{2}=9, \mathrm{p}>0.05\right)$ and females $\left(D=0.125, N_{1}=24, N_{2}=12, \mathrm{p}>0.05\right)$. This result supports our use of the pooled $10 \mathrm{yr}$ sample for estimation of age structure, annual average growth, and variance of size-at-age.

The 31 year classes of males and the 39 of females were classified into 5 and 6 age classes, respectively (Fig 2), although the first age class of females is very poorly represented (see Fig. 5). For the male LFD, the forward reading yielded an age classification by application of steps (1) and (2) of our procedure, with no alteration of the ordered sequence of year classes into ascending mean size (Table 2, Fig. 2). This is a consequence of the agreement between both fundamental assumptions. Conversely, the backward reading implied 3 alterations of the ordered sequence to avoid the existence of missing year classes in age classes III, IV. 
and $V$ (Table 2). Therefore, the forward procedure yielded the least alteration of the ordered sequence and was accepted as valid for the male LFD.

The female LFD needed application of the 3 steps in our procedure, because the ordered sequence of year classes and the tentative borders between age classes yielded 5 missing year classes in both the forward and backward readings (Table 2 ). Given that both readings required the same number of alterations, none of them appeared as a superior alternative up to this point. Therefore, the final decision for age classification in females was based on the fit of the growth function.

\section{Annual growth}

The progression of mean size in Fig. 2 suggests that a simple asymptotic growth function, the von Bertalanffy equation, provides an appropriate statistical description of annual growth, for both sexes. Therefore, the von Bertalanffy equation was fitted with the 31 year classes of males classified in age classes according to the forward procedure (Fig. 3, Table 3). The 39 year classes of females were fitted to the growth function using both classifications. The forward age classification (Fig. 2) yielded reasonable parameter estimates and a good overall quality of the fit (Table 3, Fig. 3). On the contrary, the backward age classifications yielded unreasonable parameter estimates $\left[C L_{\infty}=95.763, \mathrm{SE}\left(\mathrm{CL}_{\infty}\right)=42.2 ; k=0.053, \mathrm{SE}(k)=\right.$ $\left.0.031, t_{0}=-1.576, \mathrm{SE}\left(t_{0}\right)=0.464\right]$ (see growth equation in Table 3), and an overall lower statistical quality of the analysis (higher residual sum of squares, higher coefficient of variation of parameter estimates, and lower goodness of fit). Therefore, the forward age classification was accepted as valid for females and used for subsequent analyses. Residuals of the fitted functions showed a behavior coincident with the assumptions of randomness and variance homogeneity (Fig. 3).

In comparing the growth equations for both sexes, it appears that females are smaller than males at early ages (<age class II) but are larger at late ages (Fig. 3). Parameters of the fitted functions are fairly different (Table 3). This apparent difference in growth between the sexes was corroborated using ARSS modified for nonlinear least-squares $\left(F_{3,64}=7.240, \mathrm{p}<0.01\right)$

Linear regression results for the relationship between $\ln$ (length) and In(mass) show that both sexes differ in mass at length (partial $F_{2,716}=106.1, \mathrm{p}<0.01$ ). Therefore, the length-mass relationship was parameterized for both sexes separately (Table 3). When small (less than duoui $2 \overline{2} \mathrm{~mm}$ (i), males are significantly heavier than females of equal length, but when large the opposite is true (Fig. 4).

\section{Age of recruitment to the fishery}

The average age at which Heterocarpus reedi is completely recruited to the fishing fleet corresponds to our age class IV for both sexes (Fig. 5). This age corresponds to an average size of complete recruitment to the fishing fleet of ca $25 \mathrm{~mm}$ CL in males and $26 \mathrm{~mm}$ CL in females.

\section{Variance of size-at-age}

The within-year-class variance was larger than the among-year-classes variance of size-at-age for all agesex combinations (Fig. 5). This implies that for all ages and both sexes, the pre-settlement processes are more important than the post-settlement processes of benthic life in determining the magnitude of variance of size-at-age. Moreover, the within-year-class variance remained constant through all ages for both sexes (Fig. 5), implying that this inherent variance of the year classes is a conservative quantity that does not change with age.

In comparing the indeterminacy in size-at-age of the shrimp Heterocarpus reedi and the squat lobster Pleuroncodes monodon (Roa 1993), the across-ages coefficient of variation in size-at-age for both variance terms - within and among year classes - showed similar values for both sexes (Table 4).

\section{DISCUSSION}

\section{Age structure}

The classification of year classes into age classes from a multiple sample of LFD using our procedure yielded reasonable results for the shrimp Heterocarpus reedi of the continental shelf and upper slope off central Chile. The method as stated in this paper is a simple conceptual clarification of the original idea by Roa (1993), based on 2 fundamental assumptions, namely that individuals grow as they age and that only 1 year class from year $y$ must belong to age class a due to the existence of an annual cycle of recruitment. This annual cycle may be a single pulse or a set of pulses of recruitment with seasonal periodicity. That is, the assumption allows for the occurrence of several recruitment events if they appear with seasonal cyclical behavior. For the particular case of $H$. reedi, the assumption of annual recruitment periodicity has been supported by evidence from the monthly progression of proportional maturity at length (Campodónico et al. unpubl.), and we believe it can be proved valid for most crustacean species in temperate waters. 
Male
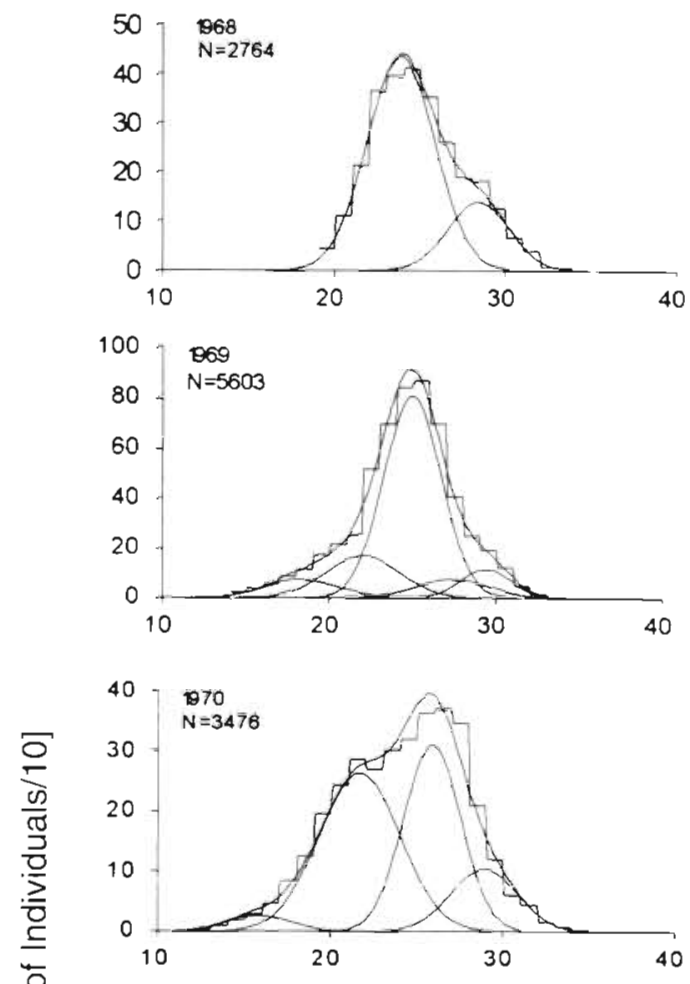

$\stackrel{\circ}{2}$
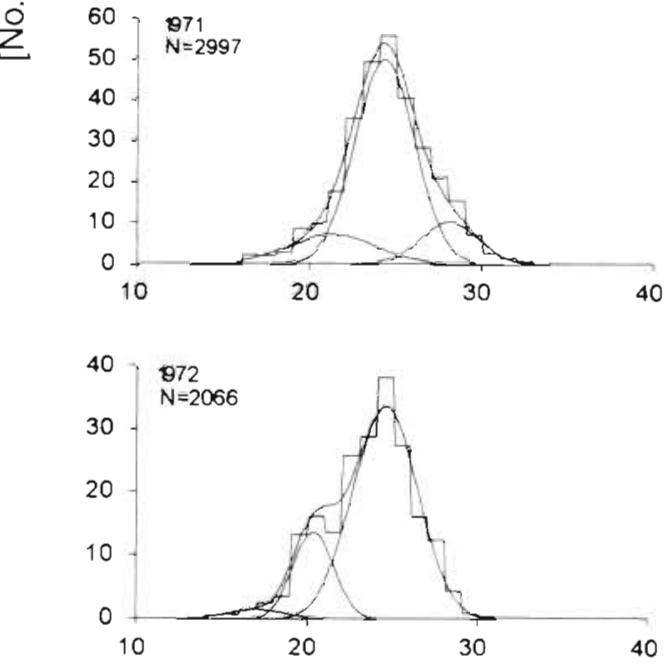

Female
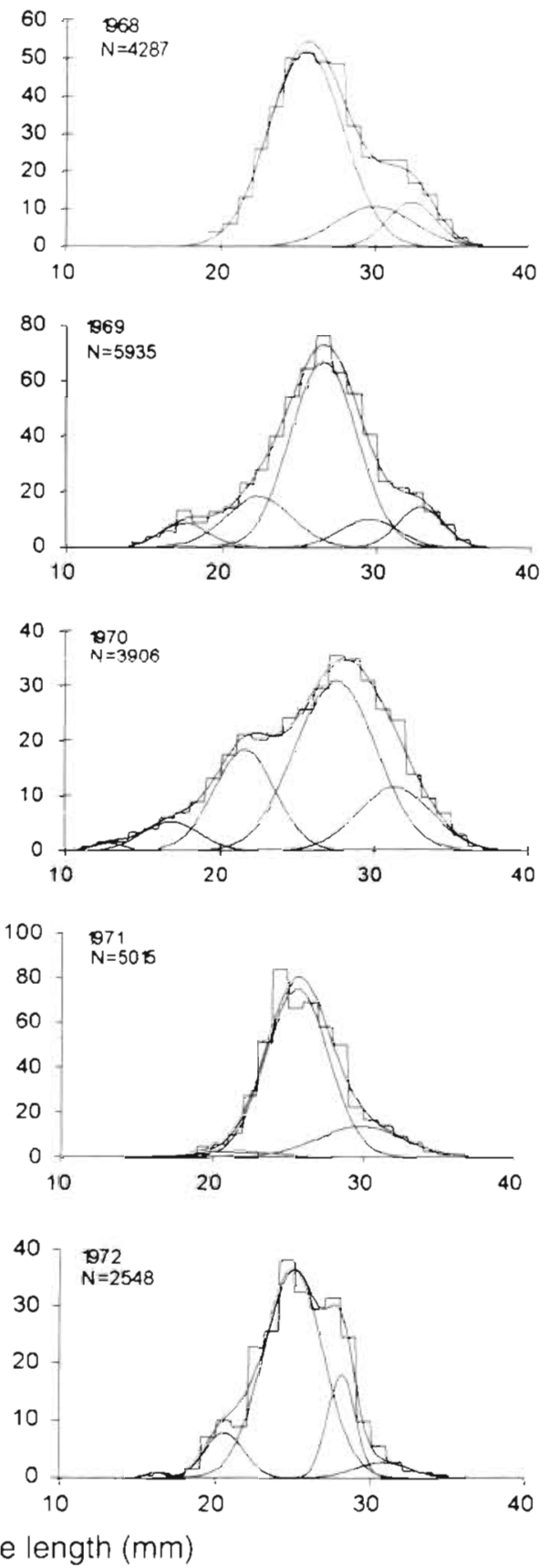

Fig. 1 (continued across page). Heterocarpus reedi. Year class composition of length-frequency data from MIX analysis. Histograms: raw data; lines: estimated normal components and fitted distribution mixture

According to evidence of sampling of the catch, the exploited fraction of the population of Heterocarpus reedi is almost completely made up of 5 age classes, with full recruitment to the fishing fleet at age IV This age class is fully represented with year classes in both sexes. We expect that in the vast majority of cases in which our method can be employed, there would be an age class fully represented with year classes (the age class of complete recruitment to the fishing fleet or gear), so that if there are pyears of data, then this fully represented age class must contain $p$ year classes. This would be valid as long as the age structure of the population remains stable during the period covered by the data. 
Male
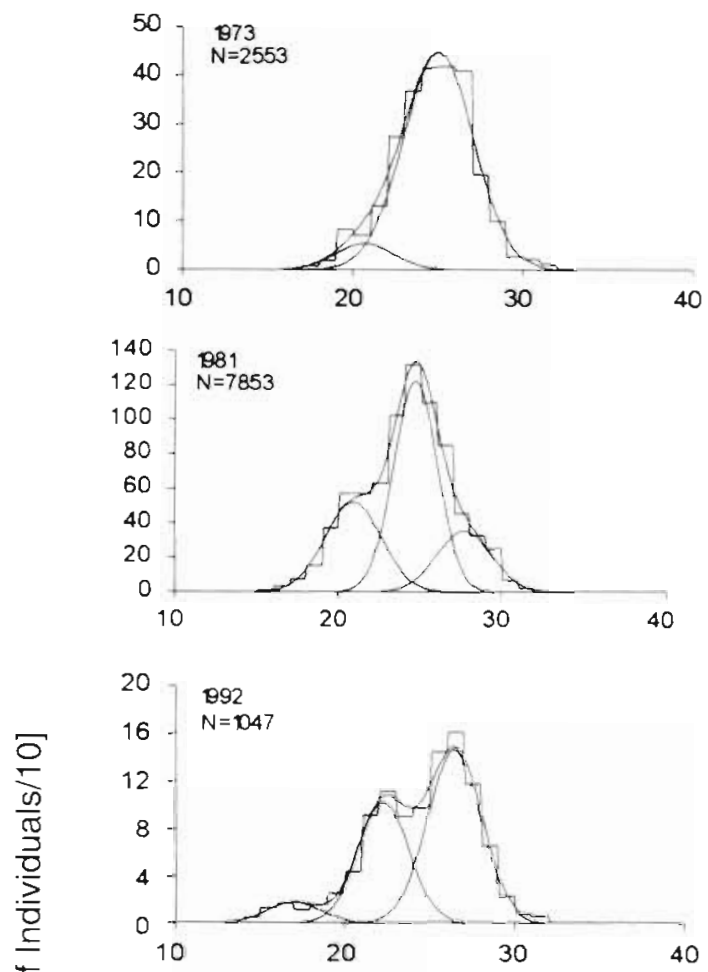

¿ํ
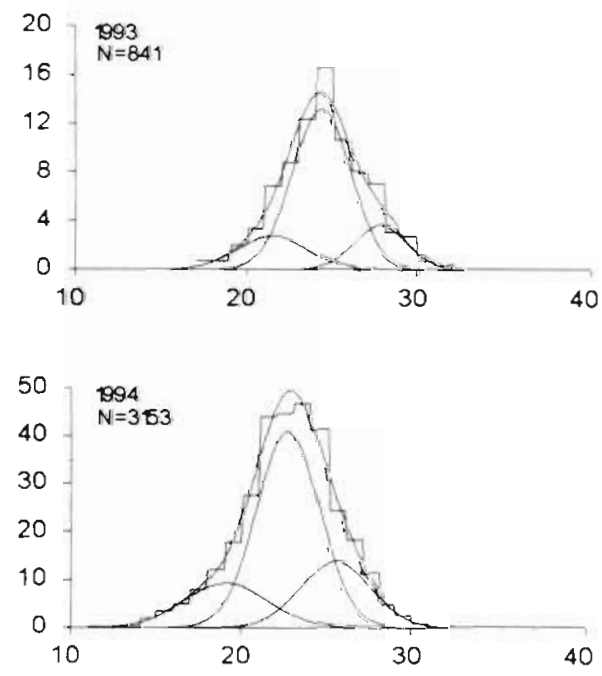

Female
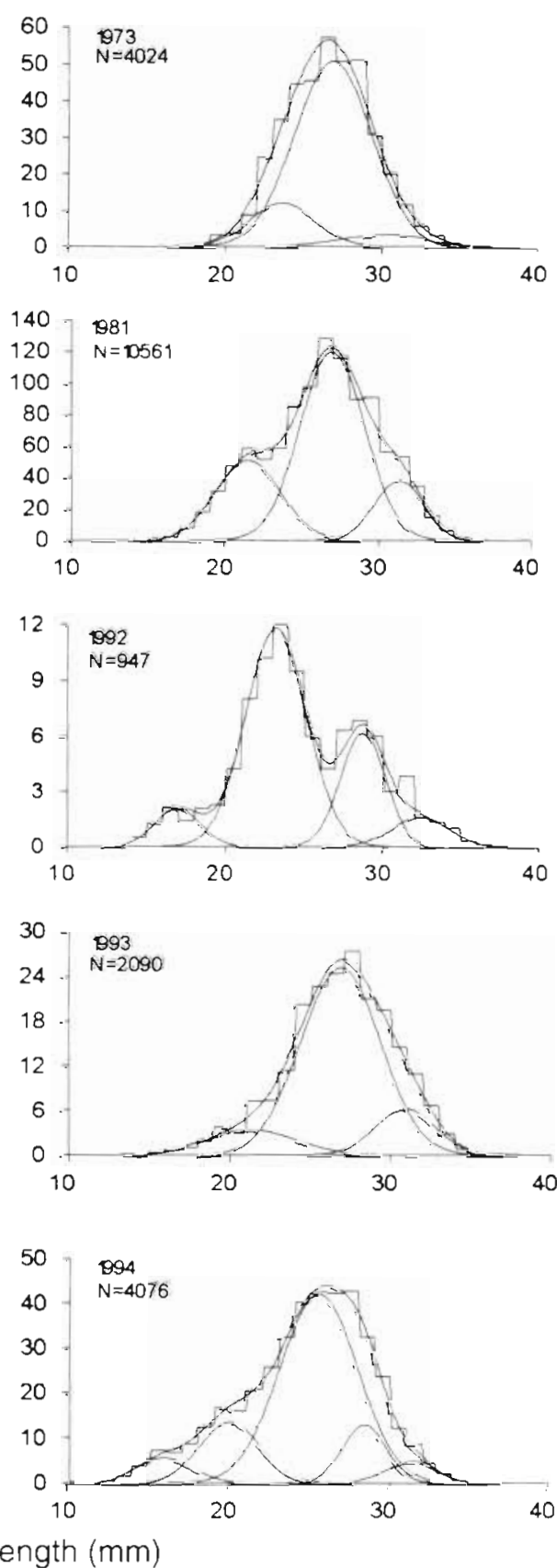

It is not possible to learn actual ages without a knowledge of juvenile year classes, not represented in our data set. However, by extending to Heterocarpus reedi our results with the similarly sized squat Iobster (Roa 1993, Roa et al. 1995), for which we obtained a representation of the whole age structure, we may proposc that there are 2 juvenile age ciasses not represented in the present study (actually one of them is very poorly represented in females; see Fig. 5). This proposition is further supported by the estimated $t_{0}$ parameter of the growth function, which yielded a reasonable estimate (Table 3 ) when fitting the function with our assumed actual ages. This position parameter predicts a mean size for newly settled individuals around $5 \mathrm{~mm} \mathrm{CL}$ for both sexes, which is quite sımilar to the mean size of newly settled squat lobsters (Roa et al. 1995), a similarly sized decapod of the continental shelf off central Chile. Therefore, the 
Table 1. Heterocarpus reedi. Results from. MIX analysıs. Year classes are ordered into ascending mean size. SD: standard deviation; P. proportion of participation in the distribution mixture. Standard error in parentheses. Mean size fixed in estimation

\begin{tabular}{|c|c|c|c|c|c|c|c|c|}
\hline \multirow{2}{*}{$\begin{array}{l}\text { Year } \\
\text { class }\end{array}$} & \multicolumn{4}{|c|}{ Males } & \multicolumn{4}{|c|}{ Females } \\
\hline & $\begin{array}{l}\text { Sampling date } \\
\text { (year) }\end{array}$ & $\begin{array}{l}\text { Mean } \\
(\mathrm{mm})\end{array}$ & $\underset{(\mathrm{mm})}{\mathrm{SD}}$ & $\mathrm{P}$ & $\begin{array}{l}\text { Sampling date } \\
\text { (year) }\end{array}$ & $\begin{array}{l}\text { Mean } \\
(\mathrm{mm})\end{array}$ & $\begin{array}{c}\mathrm{SD} \\
(\mathrm{mm})\end{array}$ & $P$ \\
\hline 1 & 1970 & $\begin{array}{l}15.80 \\
(0.28)\end{array}$ & $\begin{array}{c}1.88 \\
(0.22)\end{array}$ & $\begin{array}{c}0.036 \\
(0.004)\end{array}$ & 1970 & $\begin{array}{r}12.80 \\
(0.32)\end{array}$ & $\begin{array}{c}1.06 \\
(0.24)\end{array}$ & $\begin{array}{c}0.009 \\
(0.002)\end{array}$ \\
\hline 2 & 1972 & $\begin{array}{l}16.98 \\
(0.37)\end{array}$ & $\begin{array}{l}1.80 \\
(0.28)\end{array}$ & $\begin{array}{c}0.033 \\
(0.005)\end{array}$ & 1994 & $\begin{array}{l}15.90 \\
(0.19)\end{array}$ & $\begin{array}{l}1.75 \\
(0.14)\end{array}$ & $\begin{array}{c}0.060 \\
(0.004)\end{array}$ \\
\hline 3 & 1992 & $\begin{array}{l}17.05 \\
(0.30)\end{array}$ & $\begin{array}{l}1.57 \\
(0.23)\end{array}$ & $\begin{array}{c}0.067 \\
(0.008)\end{array}$ & 1972 & $\begin{array}{l}16.14 \\
(0.26)\end{array}$ & $\begin{array}{c}0.67 \\
(0.21)\end{array}$ & $\begin{array}{c}0.006 \\
(0.002)\end{array}$ \\
\hline 4 & 1969 & $\begin{array}{l}18.33 \\
(0.48)\end{array}$ & $\begin{array}{l}2.17 \\
(0.32)\end{array}$ & $\begin{array}{c}0.071 \\
(0.005)\end{array}$ & 1970 & $\begin{array}{c}16.81 \\
(0.22)\end{array}$ & $\begin{array}{c}1.85 \\
(0.19)\end{array}$ & $\begin{array}{c}0.062 \\
(0.006)\end{array}$ \\
\hline 5 & 1994 & $\begin{array}{l}19.16 \\
(0.21)\end{array}$ & $\begin{array}{c}2.45 \\
(0.16)\end{array}$ & $\begin{array}{c}0.182 \\
(0.010)\end{array}$ & 1992 & $\begin{array}{l}16.97 \\
(0.25)\end{array}$ & $\begin{array}{c}1.42 \\
(0.20)\end{array}$ & $\begin{array}{c}0.079 \\
(0.010)\end{array}$ \\
\hline 6 & 1972 & $\begin{array}{l}20.38 \\
(0.10)\end{array}$ & $\begin{array}{c}1.19 \\
(0.09)\end{array}$ & $\begin{array}{c}0.196 \\
(0.011)\end{array}$ & 1969 & $\begin{array}{l}17.49 \\
(0.14)\end{array}$ & $\begin{array}{c}1.52 \\
(0.11)\end{array}$ & $\begin{array}{r}0.055 \\
(0.004)\end{array}$ \\
\hline 7 & 1973 & $\begin{array}{l}20.69 \\
(0.22)\end{array}$ & $\begin{array}{c}1.70 \\
(0.16)\end{array}$ & $\begin{array}{c}0.091 \\
(0.008)\end{array}$ & 1994 & $\begin{array}{l}20.01 \\
(0.15)\end{array}$ & $\begin{array}{c}1.88 \\
(0.15)\end{array}$ & $\begin{array}{c}0.156 \\
(0.008)\end{array}$ \\
\hline 8 & 1981 & $\begin{array}{l}20.91 \\
(0.06)\end{array}$ & $\begin{array}{c}1.72 \\
(0.04)\end{array}$ & $\begin{array}{c}0.287 \\
(0.006)\end{array}$ & 1972 & $\begin{array}{l}20.59 \\
(0.14)\end{array}$ & $\begin{array}{c}1.26 \\
(0.12)\end{array}$ & $\begin{array}{c}0.097 \\
(0.009)\end{array}$ \\
\hline 9 & 1971 & $\begin{array}{l}21.24 \\
(0.26)\end{array}$ & $\begin{array}{c}2.47 \\
(0.20)\end{array}$ & $\begin{array}{c}0.146 \\
(0.009)\end{array}$ & $19 \overline{9} 3$ & $\begin{array}{l}21.27 \\
(0.33)\end{array}$ & $\begin{array}{c}2.79 \\
(0.26)\end{array}$ & $\begin{array}{c}0.114 \\
(0.008)\end{array}$ \\
\hline 10 & 1993 & $\begin{array}{l}21.54 \\
(0.49)\end{array}$ & $\begin{array}{c}2.04 \\
(0.38)\end{array}$ & $\begin{array}{c}0.167 \\
(0.016)\end{array}$ & 1971 & $\begin{array}{l}21.29 \\
(0.49)\end{array}$ & $\begin{array}{c}2.71 \\
(0.37)\end{array}$ & $\begin{array}{c}0.033 \\
(0.004)\end{array}$ \\
\hline 11 & 1970 & $\begin{array}{l}21.68 \\
(0.09)\end{array}$ & $\begin{array}{l}2.35 \\
0.09)\end{array}$ & $\begin{array}{c}0.447 \\
(0.012)\end{array}$ & 1981 & $\begin{array}{l}21.48 \\
(0.06 !\end{array}$ & $\begin{array}{l}2.12 \\
10.051\end{array}$ & $\begin{array}{r}0.255 \\
(0.005)\end{array}$ \\
\hline 12 & 1969 & $\begin{array}{l}22.02 \\
(0.12)\end{array}$ & $\begin{array}{c}2.22 \\
(0.49)\end{array}$ & $\begin{array}{c}0.167 \\
(0.010)\end{array}$ & 1970 & $\begin{array}{l}21.59 \\
(0.12)\end{array}$ & $\begin{array}{c}1.99 \\
(0.11)\end{array}$ & $\begin{array}{c}0.235 \\
(0.009)\end{array}$ \\
\hline 13 & 1992 & $\begin{array}{l}22.30 \\
(0.12)\end{array}$ & $\begin{array}{c}1.49 \\
(0.10)\end{array}$ & $\begin{array}{c}0.364 \\
(0.018)\end{array}$ & 1969 & $\begin{array}{l}22.36 \\
(0.21)\end{array}$ & $\begin{array}{c}2.16 \\
(0.22)\end{array}$ & $\begin{array}{c}0.167 \\
(0.008)\end{array}$ \\
\hline 14 & 1994 & $\begin{array}{l}22.71 \\
(0.08)\end{array}$ & $\begin{array}{c}1.82 \\
(0.09)\end{array}$ & $\begin{array}{c}0.592 \\
\{0.015\}\end{array}$ & 1992 & $\begin{array}{l}23.24 \\
(0.11)\end{array}$ & $\begin{array}{c}1.94 \\
(0.10)\end{array}$ & $\begin{array}{c}0.607 \\
(0.018)\end{array}$ \\
\hline 15 & 1968 & $\begin{array}{l}23.86 \\
(0.05)\end{array}$ & $\begin{array}{c}1.96 \\
(0.04)\end{array}$ & $\begin{array}{c}0.774 \\
(0.010)\end{array}$ & 1973 & $\begin{array}{l}23.66 \\
(0.43)\end{array}$ & $\begin{array}{c}2.10 \\
(0.20)\end{array}$ & $\begin{array}{c}0.156 \\
(0.009)\end{array}$ \\
\hline 16 & 1993 & $\begin{array}{l}24.34 \\
(0.13)\end{array}$ & $\begin{array}{l}1.70 \\
(0.14)\end{array}$ & $\begin{array}{c}0.663 \\
(0.023)\end{array}$ & 1972 & $\begin{array}{l}25.01 \\
(0.06)\end{array}$ & $\begin{array}{c}1.93 \\
(0.06)\end{array}$ & $\begin{array}{r}0.695 \\
(0.014)\end{array}$ \\
\hline 17 & 1971 & $\begin{array}{l}24.35 \\
(0.06)\end{array}$ & $\begin{array}{c}1.72 \\
(0.05)\end{array}$ & $\begin{array}{c}0.713 \\
(0.013)\end{array}$ & 1968 & $\begin{array}{l}25.47 \\
(0.07)\end{array}$ & $\begin{array}{c}2.41 \\
(0.05)\end{array}$ & $\begin{array}{c}0.732 \\
(0.009)\end{array}$ \\
\hline 18 & 1972 & $\begin{array}{l}24.56 \\
(0.06)\end{array}$ & $\begin{array}{c}1.89 \\
(0.04)\end{array}$ & $\begin{array}{c}0.770 \\
(0.011)\end{array}$ & 1994 & $\begin{array}{l}25.53 \\
(0.08)\end{array}$ & $\begin{array}{c}2.43 \\
(0.10)\end{array}$ & $\begin{array}{c}0.628 \\
(0.012)\end{array}$ \\
\hline 19 & 1981 & $\begin{array}{l}24.70 \\
(0.03)\end{array}$ & $\begin{array}{c}1.34 \\
(0.03)\end{array}$ & $\begin{array}{c}0.525 \\
(0.008)\end{array}$ & .1971 & $\begin{array}{l}25.56 \\
(0.05)\end{array}$ & $\begin{array}{c}2.08 \\
(0.04)\end{array}$ & $\begin{array}{c}0.776 \\
(0.009)\end{array}$ \\
\hline 20 & 1969 & $\begin{array}{l}25.00 \\
10.08)\end{array}$ & $\begin{array}{c}1.71 \\
(0.06)\end{array}$ & $\begin{array}{c}0.615 \\
(0.015)\end{array}$ & 1969 & $\begin{array}{l}26.58 \\
(0.11)\end{array}$ & $\begin{array}{c}2.15 \\
(0.19)\end{array}$ & $\begin{array}{c}0.604 \\
(0.011)\end{array}$ \\
\hline 21 & 1973 & $\begin{array}{l}25.03 \\
(0.05)\end{array}$ & $\begin{array}{c}2.08 \\
(0.04)\end{array}$ & $\begin{array}{c}0.909 \\
(0.008)\end{array}$ & 1993 & $\begin{array}{l}26.85 \\
(0.09)\end{array}$ & $\begin{array}{c}2.48 \\
\{0.10\}\end{array}$ & $\begin{array}{c}0.747 \\
(0.015)\end{array}$ \\
\hline 22 & 1994 & $\begin{array}{l}25.61 \\
(0.21)\end{array}$ & $\begin{array}{l}2.08 \\
(0.15)\end{array}$ & $\begin{array}{c}0.228 \\
(0.114)\end{array}$ & 1973 & $\begin{array}{l}26.89 \\
(0.08)\end{array}$ & $\begin{array}{c}2.48 \\
(0.13)\end{array}$ & $\begin{array}{r}0.783 \\
(0.012)\end{array}$ \\
\hline 23 & 1970 & $\begin{array}{l}25.91 \\
(0.07)\end{array}$ & $\begin{array}{c}1.66 \\
(0.09)\end{array}$ & $\begin{array}{c}0.371 \\
(0.014)\end{array}$ & 1981 & $\begin{array}{l}26.98 \\
(0.04)\end{array}$ & $\begin{array}{c}2.08 \\
(0.04)\end{array}$ & $\begin{array}{c}0.597 \\
(0.006)\end{array}$ \\
\hline 24 & 1992 & $\begin{array}{l}26.51 \\
(0.09)\end{array}$ & $\begin{array}{c}1.62 \\
(0.07)\end{array}$ & $\begin{array}{c}0.568 \\
(0.018)\end{array}$ & 1970 & $\begin{array}{l}27.51 \\
(0.11)\end{array}$ & $\begin{array}{c}2.61 \\
(0.14)\end{array}$ & $\begin{array}{c}0.516 \\
(0.013)\end{array}$ \\
\hline 25 & 1969 & $\begin{array}{c}27.4 \hat{1} \\
(\cdot)\end{array}$ & $\begin{array}{c}2.21 \\
(0.48)\end{array}$ & $\begin{array}{c}0.072 \\
(0.015)\end{array}$ & 1972 & $\begin{array}{l}28.14 \\
(0.09)\end{array}$ & $\begin{array}{c}0.89 \\
(0.08)\end{array}$ & $\begin{array}{c}0.156 \\
(0.012)\end{array}$ \\
\hline 26 & 1981 & $\begin{array}{l}27.73 \\
(0.081\end{array}$ & $\begin{array}{c}168 \\
(0.06)\end{array}$ & $\begin{array}{c}0.188 \\
(0.005)\end{array}$ & 1994 & $\begin{array}{l}28.40 \\
(0.27)\end{array}$ & $\begin{array}{l}1.35 \\
(0.18)\end{array}$ & $\begin{array}{r}0.107 \\
(0.012)\end{array}$ \\
\hline 27 & 1993 & $\begin{array}{l}27.88 \\
(0.24)\end{array}$ & $\begin{array}{c}1.57 \\
(0.19)\end{array}$ & $\begin{array}{c}0.169 \\
(0.017)\end{array}$ & 1992 & $\begin{array}{l}28.75 \\
(0.16)\end{array}$ & $\begin{array}{c}1.42 \\
(0.14)\end{array}$ & $\begin{array}{c}0.233 \\
(0.018)\end{array}$ \\
\hline 28 & 1971 & $\begin{array}{l}28.18 \\
(0.14)\end{array}$ & $\begin{array}{c}1.68 \\
(0.11)\end{array}$ & $\begin{array}{c}0.142 \\
(0.009)\end{array}$ & 1969 & $\begin{array}{l}29.48 \\
(0.93)\end{array}$ & $\begin{array}{l}1.89 \\
(0.83)\end{array}$ & $\begin{array}{c}0.082 \\
(0.009)\end{array}$ \\
\hline 29 & 1968 & $\begin{array}{l}28.46 \\
(0.11)\end{array}$ & $\begin{array}{c}1.79 \\
(0.08)\end{array}$ & $\begin{array}{c}0.226 \\
(0.010)\end{array}$ & 1971 & $\begin{array}{l}29.78 \\
(0.17)\end{array}$ & $\begin{array}{c}2.82 \\
(0.13)\end{array}$ & $\begin{array}{c}0.191 \\
(0.008)\end{array}$ \\
\hline 30 & 1970 & 28.94 & $\begin{array}{c}1.96 \\
(0.12)\end{array}$ & $\begin{array}{c}0.146 \\
(0.009)\end{array}$ & 1968 & $\begin{array}{l}29.95 \\
(0.30)\end{array}$ & $\begin{array}{c}2.53 \\
(0.30)\end{array}$ & $\begin{array}{c}0.158 \\
(0.010)\end{array}$ \\
\hline 31 & 1969 & $\begin{array}{c}29.36 \\
(\cdot)\end{array}$ & $\begin{array}{l}1.50 \\
(0.13)\end{array}$ & $\begin{array}{c}0.075 \\
(0.007)\end{array}$ & 1973 & $\begin{array}{l}30.29 \\
(1.09)\end{array}$ & $\begin{array}{c}2.98 \\
(0.65)\end{array}$ & $\begin{array}{c}0.060 \\
(0.007)\end{array}$ \\
\hline
\end{tabular}


Table 1 (continued)

\begin{tabular}{|c|c|c|c|c|c|c|c|c|}
\hline \multirow{2}{*}{$\begin{array}{l}\text { Year } \\
\text { class }\end{array}$} & \multicolumn{4}{|c|}{ Males } & \multicolumn{4}{|c|}{ Females } \\
\hline & $\begin{array}{l}\text { Sampling date } \\
\text { (year) }\end{array}$ & $\begin{array}{l}\text { Mean } \\
(\mathrm{mm})\end{array}$ & $\begin{array}{c}\mathrm{SD} \\
(\mathrm{mm})\end{array}$ & $\mathrm{P}$ & $\begin{array}{l}\text { Sampling date } \\
\text { (year) }\end{array}$ & $\begin{array}{l}\text { Mean } \\
(\mathrm{mm})\end{array}$ & $\begin{array}{c}\mathrm{SD} \\
(\mathrm{mm})\end{array}$ & P \\
\hline 32 & & & & & 1972 & $\begin{array}{l}30.79 \\
(0.28)\end{array}$ & $\begin{array}{c}1.76 \\
(0.21)\end{array}$ & $\begin{array}{c}0.046 \\
(0.005)\end{array}$ \\
\hline 33 & & & & & 1993 & $\begin{array}{l}30.91 \\
(0.28)\end{array}$ & $\begin{array}{c}1.86 \\
(0.18)\end{array}$ & $\begin{array}{c}0.139 \\
(0.012)\end{array}$ \\
\hline 34 & & & & & 1970 & $\begin{array}{l}31.32 \\
(0.31)\end{array}$ & $\begin{array}{c}2.42 \\
(0.19)\end{array}$ & $\begin{array}{c}0.178 \\
(0.010)\end{array}$ \\
\hline 35 & & & & & 1981 & $\begin{array}{l}31.38 \\
(0.07)\end{array}$ & $\begin{array}{l}1.64 \\
(0.05)\end{array}$ & $\begin{array}{c}0.148 \\
(0.004)\end{array}$ \\
\hline 36 & & & & & 1994 & $\begin{array}{l}31.51 \\
(0.25)\end{array}$ & $\begin{array}{c}1.70 \\
(0.18)\end{array}$ & $\begin{array}{c}0.049 \\
(0.007)\end{array}$ \\
\hline 37 & & & & & 1968 & $\begin{array}{l}32.36 \\
(0.21)\end{array}$ & $\begin{array}{c}1.58 \\
(0.12)\end{array}$ & $\begin{array}{c}0.110 \\
(0.007)\end{array}$ \\
\hline 38 & & & & & 1992 & $\begin{array}{l}32.50 \\
(0.35)\end{array}$ & $\begin{array}{c}1.86 \\
(0.26)\end{array}$ & $\begin{array}{c}0.081 \\
(0.012)\end{array}$ \\
\hline 39 & & & & & 1969 & $\begin{array}{l}32.79 \\
(0.18)\end{array}$ & $\begin{array}{c}1.47 \\
(0.11)\end{array}$ & $\begin{array}{c}0.091 \\
(0.005)\end{array}$ \\
\hline
\end{tabular}

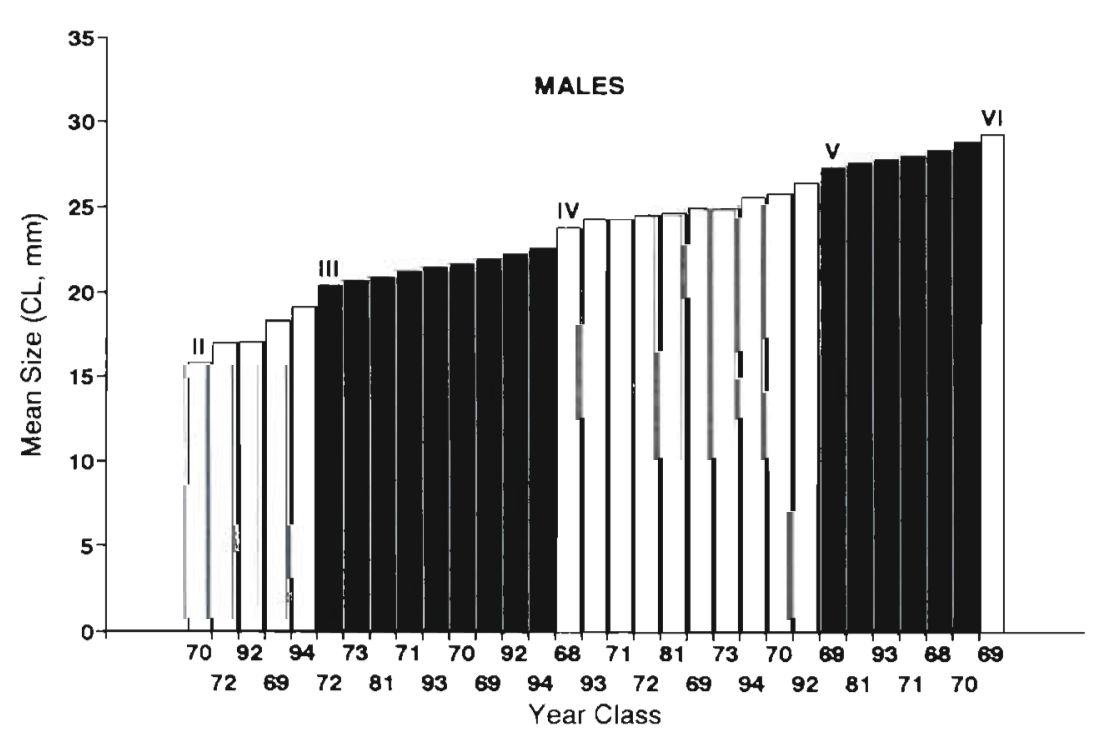

Fig. 2. Heterocarpus reedi. Mean size of year classes identified by MTX On the abcissa the calendar year. Adjacent age classes are shown by contrasting fill patterns

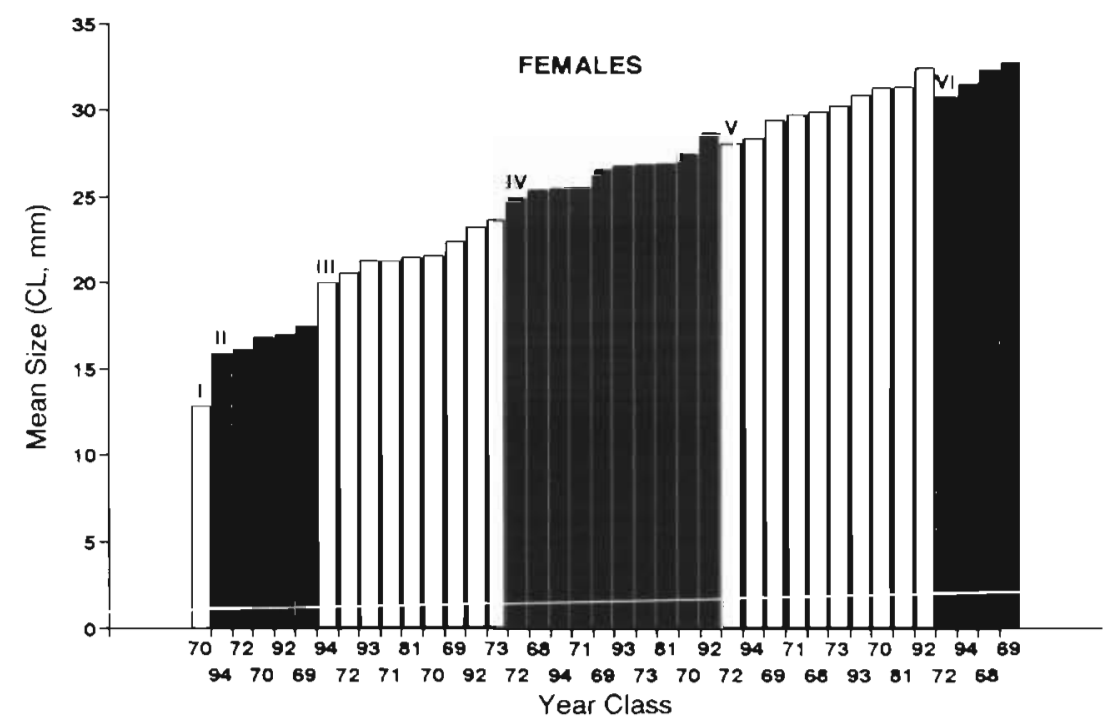


Table 2. Heterocarpus reedi. Year classes ordered into ascending mean size and classified into age classes using forward and backward procedures. Year-classes given in bold type were moved to adjacent age classes to comply with the assumption of no missing year clases

\begin{tabular}{|c|c|c|}
\hline Age & $\begin{array}{c}\text { Year classes } \\
\text { Forward analysis }\end{array}$ & $\begin{array}{c}\text { Year classes } \\
\text { Backward analysis }\end{array}$ \\
\hline \multicolumn{3}{|c|}{ Males } \\
\hline II & 7072926994 & 70729269 \\
\hline III & 727381719370699294 & 9472738171937069 \\
\hline IV & 68937172816973947092 & 9294689371728169 \\
\hline v & 698193716870 & 7394709269 \\
\hline VI & 69 & 819371687069 \\
\hline \multicolumn{3}{|c|}{ Females } \\
\hline I & 70 & 70 \\
\hline II & 9472709269 & 9472709269 \\
\hline III & 947293718170699273 & 94729371817069 \\
\hline IV & 726894716993738170 & 92737268947169 \\
\hline V & 72949269716873 & 93738170729492697168 \\
\hline VI & 7293708194689269 & 737293708194689269 \\
\hline
\end{tabular}

complete age structure of $H$ reedi may contain 7 age classes under current exploitation conditions, with the 3 oldest fully recruited to the fishery.

\section{Annual growth}

Average annual growth in both sexes of Heterocarpus reedi follows a von Bertalanffy growth function. This is a common result for decapod crustaceans (Campbell 1983, Anderson 1991, Plaut \& Fishelson 1991, Somers \& Kirkwood 1991, Bergström 1992, Roa 1993). Our parameters for the growth function must be regarded as an average over a period of almost 30 yr, and hence they may be expected to include fluctuations in growth occurring at the time scale of decades. This estimation is a starting point for further studies on biomass
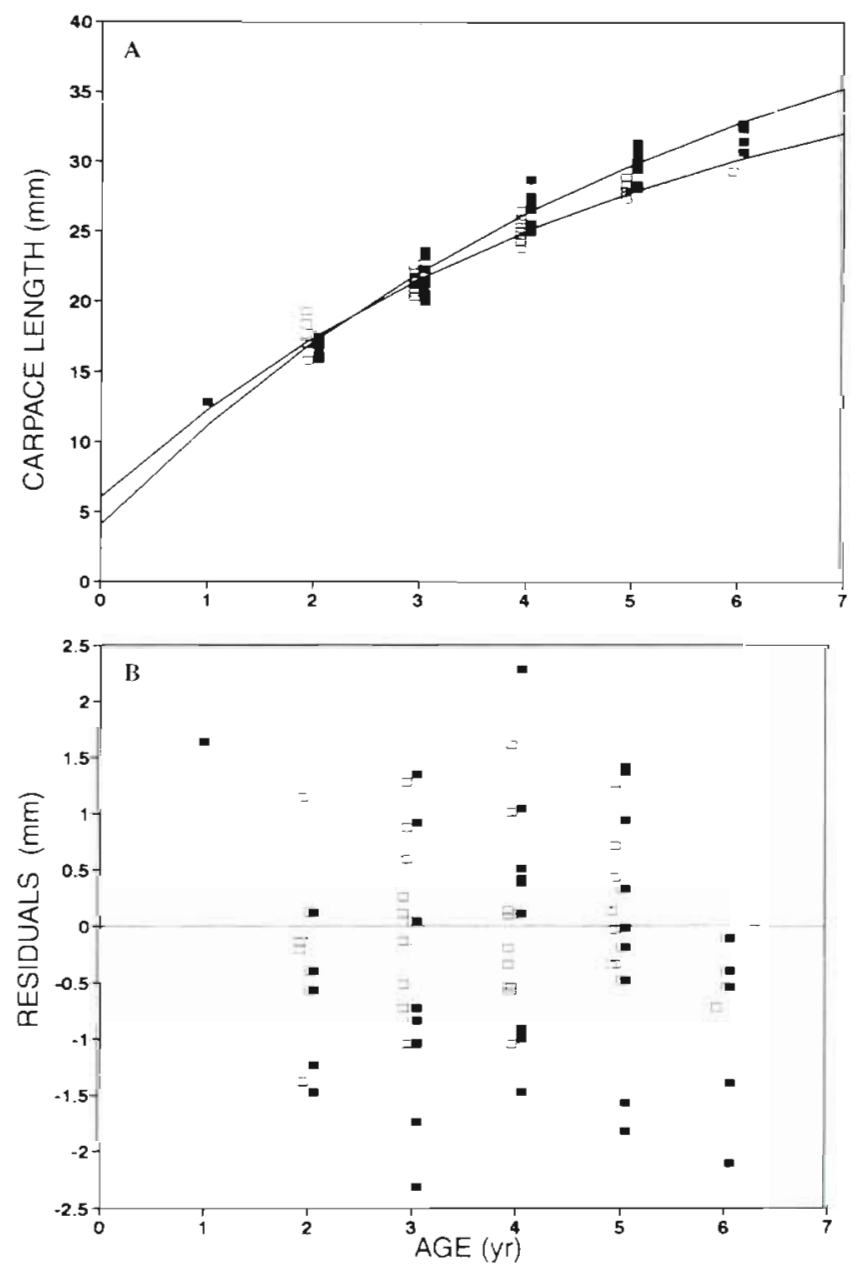

Fig. 3. Heterocarpus reed. Von Bertalanffy growth functions of male and female shrimps. (A) Fitted functions (line) and year class mean size ( $\square$ : males; $\boldsymbol{\square}$ : females) (B) residuals of the fitted functions production of this commercially exploited species, a task that must be done separately for males and females, since they show different growth rates.

Table 3. Heterocarpus reedi. Growth and body length-mass parameters and related statistical information. Standard errors in parentheses. CL: carapace length; a: age; $w$ : body mass

\begin{tabular}{|lcc|}
\hline Parameter & \multicolumn{1}{c}{ Males } & Females \\
\hline Growth in length: $\mathbf{C L}=\mathbf{C L}_{\infty} \mid \mathbf{1}-\mathbf{e x p}\left[-\boldsymbol{k}\left(\boldsymbol{a}-\boldsymbol{t}_{0}\right)\right]$ \\
$\mathrm{CL}(\mathrm{mm})$ & $40.68(6.01)$ & $48.34(6.55)$ \\
$k\left(\mathrm{yr}^{-1}\right)$ & $0.199(0.07)$ & $0.174(0.05)$ \\
$t_{0}(\mathrm{yr})$ & $-0.809(0.50)$ & $-0.510(0.31)$ \\
$\mathrm{r}^{2}$ & 0.999 & 0.998 \\
Length-body & & \\
$\ln (d)$ & $-7.093(0.151)$ & $-9.422(0.164)$ \\
$b$ & $2.834(0.047)$ & $3.578(0.051)$ \\
$\mathrm{r}^{2}$ & 0.901 & 0.942 \\
\hline
\end{tabular}

Tabie 4. Heterocarpus reedi and Pleuroncodes monodon. Across-ages descruptive statıstics of variability in size-at-age

\begin{tabular}{|c|c|c|c|c|}
\hline \multirow[t]{2}{*}{ Statistic } & \multicolumn{2}{|c|}{ H. reedi } & \multicolumn{2}{|c|}{ P. monodon } \\
\hline & Males & Females & Males & Females \\
\hline Mean size (mm) & 24.2 & 26.2 & 30.2 & 26.8 \\
\hline \multicolumn{5}{|l|}{ Within year class } \\
\hline $\mathrm{SD}(\mathrm{mm})$ & 1.83 & 2.16 & 2.43 & 2.18 \\
\hline Coefficient of variation & 0.076 & 0.082 & 0.081 & 0.081 \\
\hline \multicolumn{5}{|l|}{ Among year class } \\
\hline $\mathrm{SD}(\mathrm{mm})$ & 0.78 & 1.09 & 0.84 & 0.64 \\
\hline Coefficient of variation & 0.032 & 0.042 & 0.028 & 0.024 \\
\hline
\end{tabular}




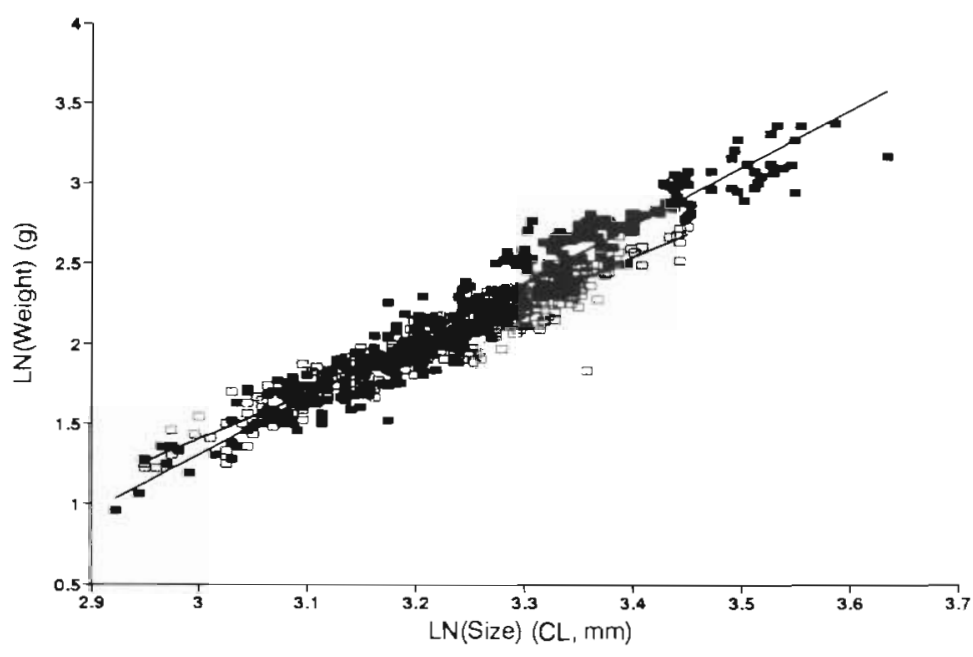

Fig. 4. Heterocarpus reedi. Regression lines for the length-body mass relationship of males $(\square)$ and females (

\section{Variance of size-at-age}

The within-year-class variance of size-atage, that inherent variance resulting from pre-settlement processes, proved to be a conservative quantity that does not change with age, for both sexes. A similar result was obtained for the squat lobster (Roa 1993). The among-year-classes variance for females was also constant through ages, meaning that environmental processes encountered in post-settlement life have no effect on total variance of size-at-age. Conversely, in males this variance decreased through age, that is, mean size-at-age converged through age. This result may be interpreted as an effect of variance reduction of post-settlement life; however, we attribute this effect to low representation of older year classes in males. In fact, age

In this species, females grow larger than males in length at age. This difference between sexes is counterintuitive in the sense that females are expected to be smaller in size due to the need to allocate energy to reproduction, except for protandric hermaphrodites, which is not the case for Heterocarpus reedi (G. Henriquez pers. comm.). One explanation is that females grow larger in length but not in body mass. Our data do not support this explanation (Fig, 4, Table 3). On the contrary, the data show that females are more massive that males of the same length at late ages. Another explanation is that the catch is overrepresented with large females, due to fleet selectivity. However, it is more likely that the fleet is selective towards females because fishermen know that females are larger. We consider that the cause of the greater female size in our results must be searched for in the biology of the species. In particular, we advance the hypothesis that females have higher feeding rates than males of similar age.

Despite the confidence provided by the long period covered by our data, our parameterization of the growth function for both sexes of Heterocarpus reedi may be affected by the size selectivity of the gear of the fishing fleet. This problem arises when the gear selects only the largest sizes of the young age classes not fully recruited to the fishing fleet, producing bias in the estimation of growth parameters (Fournier et al. 1990). For example, note in Fig. 3 that the single year class of age class I in females is âtovive the fititeu yı owin curve. A detinitive solution for this problem can only be obtained when data for juvenile year classes become available.

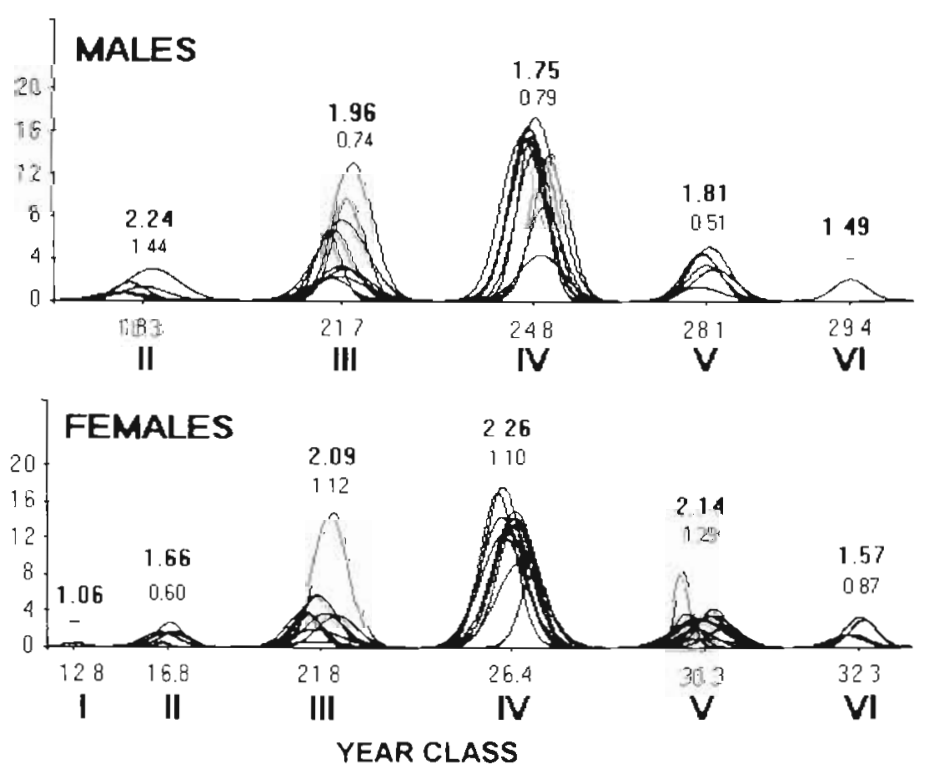

Fig. 5. Heterviánus teecis. Scaied proportion of participation of year classes in distribution muxtures by age classes, weighted mean sizeat-age, within-year-class and among-year-classes variance of size-atage 
ture of these decapod crustaceans can be attributed to processes occurring during pre-settlement life

The across-ages coefficient of variation of size-atage defined by Eq. (5) reduces to a single standardized quantity the information on both terms - within and among year classes - of variance of size-at-age. The quantity is independent of species body size and the number of ages in an age-structured population, so that across-taxa comparisons of the magnitude of indeterminacy in size-at-age can be undertaken. For example, we conclude that the shrimp Heterocarpus reedi and the squat lobster Pleuroncodes monodon, both inhabitants of the continental shelf off central Chile, have similar levels of indeterminacy in size-at-age. However, the comparison of other species in different environments may reveal differences that relate to environmental conditions and/or life history traits in a significant way.

Acknowledgements. Three anonymous referees made several comments and criticisms that prompted us to perform new analyses and contributed to clarification of our model and of the text. This work was financed by FONDECYT grant no. 1940114 to R.R.

\section{LITERATURE CITED}

Anderson PJ (1991) Age, growth, and mortality of the northern shrimp Pandalus borealis Kroyer in Pavlov Bay, Alaska. Fish Bull US 89:541-553

Bergström B (1992) Growth, growth modelling and age determination of Pandalus borealis. Mar Ecol Prog Ser 83: $167-183$

Campbell A (1983) Growth of tagged American lobster, Homarus americanus, in the Bay of Fundy. Can J Fish Aquat Sci 40:1667-1675

Chen Y, Jackson DA, Harvey HH (1992) A comparison of von Bertalanffy and polynomial functions in modelling fish growth data. Can J Fish Aquat Sci 49:1228-1235

Connell JH (1985) The consequences of variation in initial settlement vs. post-settlement mortality in rocky intertidal communities. J Exp Mar Biol Ecol 93:11-45

Doherty P, Fowler T (1994) An empirical test of recruitment limitation in a coral reef fish. Science 263:935-939

Fitz HC, Wiegert RM (1991) Tagging of juvenile blue crabs, Callinectes sapidus, with microwire tags: retentions, survival, and growth through multiple molts. J Crust Biol 11 $229-235$

Fournier DA, Breen PA (1983) Estimation of abalone mortality rates with growth analysis. Trans Am Fish Soc 112:403-411.

Fournier DA, Sibert JR, Majkowski J, Hampton J (1990) MUL. TIFAN: a likelihood-based method for estimating growth parameters and age composition from multiple length frequency data sets illustrated using data for southern

This article was submitted to the editor bluefin tuna (Thunnus maccoyii). Can J Flsh Aquat Sci 47 $301-317$

Fournier DA, Sibert JR, Terceiro M (1991) Analysis of length frequency samples with relative abundance data for the Gulf of Maine northern shrimp (Pandalus borealis) by the MULTIFAN method. Can J Fish Aquat Sci 48:591-598

France R, Holmes J, Lynch A (1991) Use of size-frequency data to estimate the age composition of crayfish populations. Can J Fish Aquat Sci 48:2324-2332

Hill C (1992) Interactions between year classes in the benthic amphipod Monoporeia affinis - effects of juvenile survival and growth. Oecologia 91:157-162

Macdonald PDM, Pitcher TJ (1979) Age-groups from size-frequency data: a versatile and efficient method of analysing distribution mixtures. J Fish Res Bd Can 36:987-1001

Megrey BA (1989) Review and comparison of age-structured stock assessment models from theoretical and applied points of view. Am Fish Soc Symp 6:92-101

Neter J, Wasserman W, Kutner MH (1985) Applied linear statistical models. Irwin, IL

Peterson CH, Summerson HC (1992) Basin-scale coherence of population dynamics of an exploited marine invertebrate, tho bay scallop: implications of recruitment limitation. Mar Ecol Prog Ser 90:257-272

Plaut 1, Fishelson L (1991) Population structure and growth in captivity of the spiny lobster Panulirus inflatus from Dahab, Gulf of Aqaba, Red Sea. Mar Biol 111:467-472

Roa R (1993) Annilal growth and maturity function of the squat lobster Pleuroncodes monodon in central Chile. Mar Ecol Prog Ser 97:157-166

Roa R, Bahamonde R (1993) Growth and expansion of an exploited population of the squat lobster Pleuroncodes monodon after 3 years without harvesting. Fish Res 18:305-319

Roa R, Gallardo VA, Ernst B, Baltazar M, Cañete Jl, EnriquezBriones S (1995) Nursery ground, age structure and abundance of juvenile squat lobster Pleuroncodes monodon on the continental shelf off central Chile. Mar Ecol Prog Ser $116: 47-54$

Sheehy M, Cameron E, Marsden G, McGrath J (1995) Age structure of female giant tiger prawns Penaeus monodon as indicated by neuronal lipofuscin concentration. Mar Ecol. Prog Ser 117:59-63

Somers IF, Kirkwood GP (1991) Population ecology of the grooved tiger prawn, Penaeus semisulcatus, in the northwestern Gulf of Carpentaria, Australia: growth, movement, age structure and infestation by the bopyrid parasite Epipenaeon ingens. Aust J Mar Freshwat Res 42:349-367

Steel RGD, Torrie JH (1985) Bioestadística: principios y procedimientos. MacGraw-Hill, Santiago

Taylor DM, Hoenig JM (1990) Growth per molt of male snow crab Chionoecetes opilio from Conception and Bonavista Bays, Newfoundland. Fish Bull (US) 88753-760

Underwood AJ, Denley EJ (1984) Paradigms, explanations and generalizations in models for the structure of inteltid.al communities on rocky shores. In: Strong DR $\mathrm{Jr}$, Simberloff D, Abele LG. Thistle AB (eds) Ecological communities: conceptual issues and the evidence. Princeton University Press, Princeton, p 151-180

Wilkinson L (1988) SYSTAT the system for statistics. SYSTAT Inc, Evanston, IL

Manuscript first received: May 22, 1995

Revised version accepted: October 26, 1995 